\title{
Facile Formation and Dissociation Behaviour of C-C Bond Resulted from the Nucleophilic Attack of Carbanions on a Carbonyl Carbon in [Pt(hfac) $\left.{ }_{2}\right]$
}

\author{
Seichi Okeya,* Masato Hashimoto, Fumiko Nakamura, ${ }^{\dagger}$ Yoshiaki Kusuyama, ${ }^{\dagger}$ Mako Kobayashi, ${ }^{\dagger \dagger}$ and Ryuichi Arakawa ${ }^{\dagger \dagger}$ \\ Department of Material Science and Chemistry, Faculty of Systems Engineering, Wakayama University, Sakaedani 930, \\ Wakayama 640-8510 \\ ${ }^{\dagger}$ Faculty of Education, Wakayama University, Sakaedani 930, Wakayama 640-8510, \\ ${ }^{\dagger}$ Department of Applied Chemistry, Kansai University, 3-3-35 Yamate-cho, Suita, Osaka 564-8680
}

(Received July 7, 2000; CL-000649)

$\left[\mathrm{Pt}(\mathrm{hfac})_{2}\right]$ (hfac: hexafluoroacetylacetonate) reacts with $\mathrm{MeNH}_{2}$ in $\mathrm{CH}_{2} \mathrm{Cl}_{2} / \mathrm{MeOH}$ to give an -NHMe adduct complex on one of the carbonyl carbons, $\left(\mathrm{MeNH}_{3}\right)[\mathrm{Pt}(\mathrm{hfac})(\mathrm{hfac}-\mathrm{NHMe})] \mathbf{1}$ which is a tetrahedral intermediate of a Schiff base complex, $\left[\mathrm{Pt}\left(\mathrm{CF}_{3} \mathrm{COCHC}(\mathrm{NMe}) \mathrm{CF}_{3}\right)_{2}\right]$ 2. Complex 1 activates $\mathrm{H}_{2} \mathrm{O}$, $\mathrm{MeOH}, \mathrm{MeNO}_{2}$ or acetone in solution to form the corresponding conjugate base adducts. The $\mathrm{C}-\mathrm{C}$ bond in $-\mathrm{CH}_{2} \mathrm{NO}_{2}$ adduct 6, easily cleaves and generates nitromethane in solution.

Metal polyamine complexes react with ketones to give macrocyclic polyimine complexes. On the contrary the reaction of ketone or ketonate complexes with amines to form imines has been scarecely reported. Though $\left[\operatorname{Pd}(\beta \text {-dik })_{2}\right](\beta$-dik $=$ acac, hfac) reacts with an excess quantity of $\mathrm{MeNH}_{2}$ to afford $\left[\mathrm{Pd}\left(\mathrm{MeNH}_{2}\right)_{4}\right](\beta \text {-dik })_{2},\left[\mathrm{Pt}(\mathrm{hfac})_{2}\right]$ gives the Schiff base complex 2, under the same reaction conditions. ${ }^{1}$ The electronattracting $\mathrm{CF}_{3}$ groups must enhance the reactivity of a carbonyl carbon in hfac ligand. HfacH reacted with water to form the bis(gem-diol) type compound 1,1,1,5,5,5-hexafluoropentane2,4-tetraol whose deprotonated tetra-anion bridged to two metal atoms to form a dinuclear Mn(III) complex. ${ }^{2}$ Recently we reported the formation and structure of a Pd(II) complex with a new $C, N$-chelate which was derived from the nucleophilic attack of a hydroxy group in the coordinating monoximes on a carbonyl carbon in a central-carbon-bonded hfac ligand. ${ }^{3}$ Primary amines attack the carbonyl carbon in ketones or aldehydes nucleophilically to form imines (Schiff base), but a tetrahedral intermediate with -NHR has never been isolated. We report here the preparation and reactions of the intermediate complex which finally becomes complex 2 .

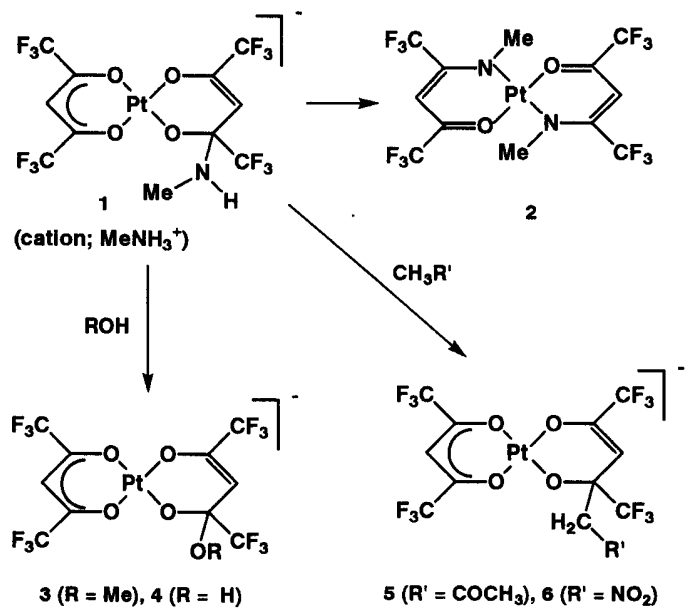

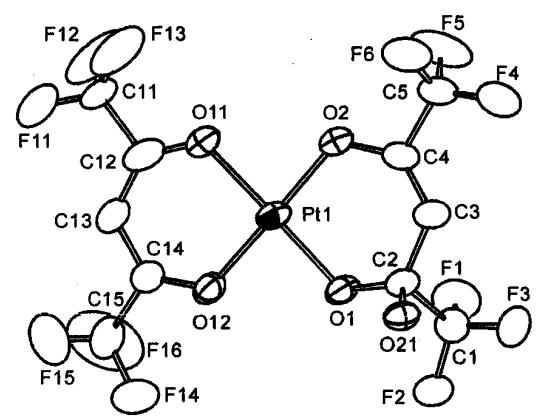

Figure 1. The structure of complex 4 with atomic notations. Selected interatomic distances (A); Pt1-O1 2.002(7), Pt1-O2 1.969(9), Pt1-O11 2.021(9), Pt1-O12 1.994(9), O1-C2 1.37(1), C2-O21 1.46(1), C2-C3 1.49(2), C3-C4 1.30(2), O2-C4 1.35(2). Bond angles around $\mathrm{C} 2$ range $105.7(9)-120.3(10)^{\circ}$.

To [ $\mathrm{Pt}(\mathrm{hfac})_{2}$ ] in $\mathrm{CH}_{2} \mathrm{Cl}_{2}$ was added two equivalents of $\mathrm{MeNH}_{2}$ in $\mathrm{MeOH}$ to immediately afford fine orange crystals of complex 1 in $84 \%$ yield. The structure of 1 was deduced to be an -NHMe adduct on one of the carbonyl carbons in [Pt(hfac) $\left.)_{2}\right]^{4}$ This means the tetrahedral intermediate of imines is first stabilized in this metal system. Complex $\mathbf{1}$ gave -OMe adduct complex 3 immediately upon dissolving in $\mathrm{MeOH}$ in situ, ${ }^{5}$ but after one day red needles of 2 appeared (28\% yield). ${ }^{6}$ The final product, 2, must have been formed via a small quantity of $\mathbf{1}$ equilibrated with metastable 3 in solution. The $-\mathrm{OH}$, $-\mathrm{CH}_{2} \mathrm{COCH}_{3}$ and $-\mathrm{CH}_{2} \mathrm{NO}_{2}$ adducts, 4-6, were also produced after dissolution of complex 1 in $\mathrm{CH}_{3} \mathrm{CN}$ (non-dried), acetone or $\mathrm{MeNO}_{2}$, respectively. ${ }^{7}$ These structures were supported by the characteristic four line signal patterns observed in the ${ }^{19} \mathrm{~F}$ NMR spectra and the existence of the parent signal in the negative mode ESI-MS. ${ }^{8}$ Red crystals of the $-\mathrm{OH}$ adduct, 4, were isolated from the reaction of $\left[\mathrm{Pt}(\mathrm{hfac})_{2}\right]$ and $n-\mathrm{Pr}_{3} \mathrm{~N}$ in wet $\mathrm{CH}_{2} \mathrm{Cl}_{2}$ (Figure 1). ${ }^{9}$ Similar $-\mathrm{OH}$ adduct with $\left[\mathrm{Co}(\mathrm{hfac})(\mathrm{NN})_{2}\right]^{2+}$ (NN $=$ ethylenediamines) has been reported. ${ }^{10}$ In an acetone solution of complex $\mathbf{1}$ some short-lived species other than $\mathbf{1}$ were detected by ESI-MS just after dissolution at low temperature (Figure 2). But a short time after elevating the temperature, only the signal of complex 5 was observed. Complex 6 was isolated from the $\mathrm{MeNO}_{2}$ solution of $\mathbf{1}$ in $75 \%$ yield as a red crystal which was X-ray analyzed (Figure 3). ${ }^{11}$ The newly formed $\mathrm{C}-\mathrm{C}$ bond length $(1.56(1) \AA)$ is slightly longer than the normal value. Complex 6 liberated free $\mathrm{CH}_{2} \mathrm{DNO}_{2}$ in $\mathrm{CD}_{3} \mathrm{OD}$ and transformed to $-\mathrm{OCD}_{3}$ adduct, $3{ }^{12}$ Complex 6 liberated $\mathrm{MeNO}_{2}$ in $\mathrm{CD}_{3} \mathrm{NO}_{2}$ and reproduced $\left[\mathrm{Pt}(\mathrm{hfac})_{2}\right.$ ] slowly. Complex 4 also equilibrated with $\left[\mathrm{Pt}(\mathrm{hfac})_{2}\right]$ in $\mathrm{CD}_{2} \mathrm{Cl}_{2}$. It is well known that various nucleophiles; e.g., $\mathrm{OH}^{-}, \mathrm{H}^{-}, \mathrm{H}_{2} \mathrm{O}, \mathrm{NH}_{3}$, 


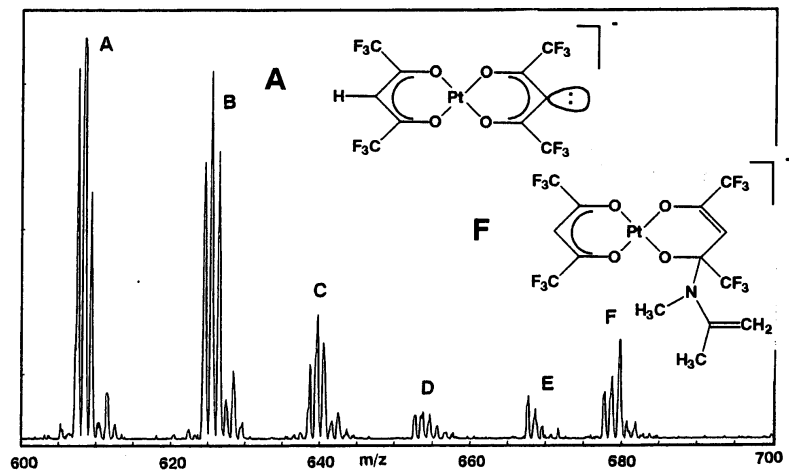

Figure 2. The negative mode ESI-MS spectrum of 1 in acetone just after dissolution at low temperature. ${ }^{8} \mathrm{~A}$; the deprotonated [Pt(hfac)2] (m/z 608), B; complex 4 (626), C; complex 1 (639), D and E; unidentified species, F; a species with the enamine type structure (679).

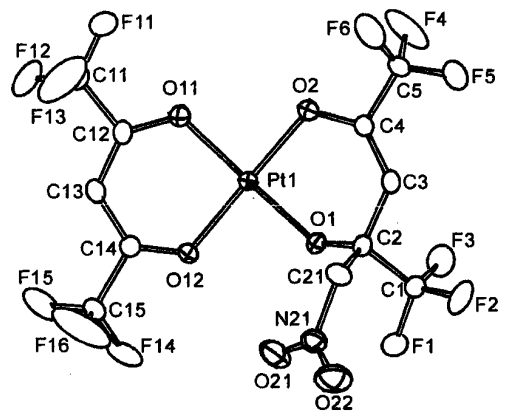

Figure 3. The structure of complex 6 with atomic notations. Selected interatomic distances (A); Pt1-O1 1.992(5), Pt1-O2 1.996(6), Pt1-O11 2.012(6), Pt1-O12 1.999(5), O1-C2 1.390(9), C2-C21 1.56(1), C21-N21 1.50(1), C2-C3 1.52(1), C3-C4 1.32(1), O2-C4 1.333(9). Bond angles around $\mathrm{C} 2$ range $105.4(9)-114.7(6)^{\circ}$.

$\mathrm{ROH}$, attack the carbonyl carbon in ketones or aldehydes and the resulting adducts attain equilibrium with ketones or aldehydes in solution. Though the carbanions also attack the carbonyl carbon using the Grignard reagent to form a $\mathrm{C}-\mathrm{C}$ bond, in this case the $\mathrm{C}-\mathrm{C}$ bond formation reaction is irreversible. Therefore the facile $\mathrm{C}-\mathrm{C}$ bond cleavage in complex $\mathbf{6}$ is quite unique. The platinum and electron-attracting $\mathrm{CF}_{3}$ groups of $\left[\mathrm{Pt}(\mathrm{hfac})_{2}\right]$ seem to lower the activation free energy of this process.

\section{References and Notes}

1 S. Okeya, H. Sazaki, M. Ogita, T. Takemoto, Y. Onuki, Y.Nakamura, B. K. Mohapatra, and S. Kawaguchi, Bull. Chem. Soc. Jpn., 54, 1978 (1981); S. Okeya, Y. Nakamura, and S. Kawaguchi, Bull. Chem. Soc. Jpn., 55, 1460 (1982).

2 E. Bouwman, K. G. Caulton, G. Christou, K. Folting, C. Gasser, D. N. Hendrickson, J. C. Huffman, E. B. Lobkovsky, J. D. Martin, P. Michel, H.-L. Tsai, and Z. Xue, Inorg Chem., 32, 3463 (1993).

3 S. Okeya, K. Taniguchi, J. Nishimura, Y. Kusuyama, I. Nagasawa, and Y. Kushi, Chem. Lett., 1997, 1095.
4 1: IR (KBr) 3070s, 3037s, 2901m, 2801m, 2608w, 2515w, $1670 \mathrm{~s}, 1594 \mathrm{vs}, 1562 \mathrm{~s}, 1533 \mathrm{~m}, 1275 \mathrm{vs}, 1238 \mathrm{vs}, 1216 \mathrm{vs}$, 1156vs, 1131s. ESI-MS in $\mathrm{CH}_{3} \mathrm{CN}$ (just after dissolution at low temperature $)^{8} \mathrm{~m} / \mathrm{z} 639\left(\mathrm{M}^{-}\right)$. Anal. Calcd for $\mathrm{C}_{12} \mathrm{H}_{12} \mathrm{~N}_{2} \mathrm{O}_{4} \mathrm{~F}_{12} \mathrm{Pt}$ : C, 21.47; H, 1.80; N, 4.17; Pt, 29.1\%. Found: C, 21.46; H, 1.75; N, 3.97; Pt, 29.1\%.

5 3: in situ (complex 1 in methanol). ESI-MS $m / z 640\left(\mathrm{M}^{-}\right)$. ${ }^{19} \mathrm{~F}$ NMR $\left(\mathrm{CD}_{3} \mathrm{NO}_{2}\right.$, Ref; External $\left.\mathrm{C}_{6} \mathrm{~F}_{6}\right) \delta 82.67(J(\mathrm{Pt}-\mathrm{F})$ $=11 \mathrm{~Hz}), 90.37(J(\mathrm{Pt}-\mathrm{F})=15 \mathrm{~Hz}), 90.53(J(\mathrm{Pt}-\mathrm{F})=14$ $\mathrm{Hz}), 92.94(J(\mathrm{Pt}-\mathrm{F})=16 \mathrm{~Hz})$.

6 2: ${ }^{13} \mathrm{C} \mathrm{NMR}\left(\left(\mathrm{CD}_{3}\right)_{2} \mathrm{CO}\right) \delta 41.3(\mathrm{q}, J(\mathrm{~F}-\mathrm{C})=4 \mathrm{~Hz}, \mathrm{NMe})$, $93.2(\mathrm{~m}, J(\mathrm{Pt}-\mathrm{C})=76 \mathrm{~Hz}, \mathrm{CH}), 117.7(\mathrm{q}, J(\mathrm{~F}-\mathrm{C})=278 \mathrm{~Hz}$, $\left.\mathrm{CF}_{3}\right), 119.0\left(\mathrm{q}, J(\mathrm{~F}-\mathrm{C})=287 \mathrm{~Hz}, \mathrm{CF}_{3}\right), 152.6(\mathrm{q}, J(\mathrm{~F}-\mathrm{C})=$ $29 \mathrm{~Hz}, \mathrm{CN}), 160.8(\mathrm{q}, J(\mathrm{~F}-\mathrm{C})=34 \mathrm{~Hz}, \mathrm{CO}) ;{ }^{19} \mathrm{~F}$ NMR $\left(\left(\mathrm{CD}_{3}\right)_{2} \mathrm{CO}\right) \delta 92.50\left(\mathrm{~J}(\mathrm{Pt}-\mathrm{F})=15 \mathrm{~Hz}, \mathrm{OCCF}_{3}\right), 101.60(\mathrm{q}$, $\left.J(\mathrm{H}-\mathrm{F})=2 \mathrm{~Hz}, J(\mathrm{Pt}-\mathrm{F})=13 \mathrm{~Hz}, \mathrm{NCCF}_{3}\right)$.

7 4: in situ (complex 1 in non-dried acetonitrile). ESI-MS $\mathrm{m} / \mathrm{z} 626\left(\mathrm{M}^{-}\right) .{ }^{19} \mathrm{~F}$ NMR $\left(1\right.$ in $\left.\mathrm{CD}_{3} \mathrm{CN}\right) \delta 81.7(J(\mathrm{Pt}-\mathrm{F})=15$ $\mathrm{Hz}), 91.2(J(\mathrm{Pt}-\mathrm{F})=14 \mathrm{~Hz}), 91.5(J(\mathrm{Pt}-\mathrm{F})=16 \mathrm{~Hz}), 93.8$ $(J(\mathrm{Pt}-\mathrm{F})=19 \mathrm{~Hz})$. 5: in situ (complex 1 in acetone). ESIMS $m / z 666\left(\mathrm{M}^{-}\right) .{ }^{19} \mathrm{~F}$ NMR $\left(\left(\mathrm{CD}_{3}\right)_{2} \mathrm{CO}\right) \delta 85.6,90.8$ $(J(\mathrm{Pt}-\mathrm{F})=14 \mathrm{~Hz}), 90.9(J(\mathrm{Pt}-\mathrm{F})=16 \mathrm{~Hz}), 94.0(J(\mathrm{Pt}-\mathrm{F})=$ $19 \mathrm{~Hz})$. 6: IR (KBr) 1665m, 1638w, 1594s, 1563s, 1549vs, $1523 \mathrm{~m}$. ESI-MS in $\mathrm{CH}_{3} \mathrm{NO}_{2} \mathrm{~m} / z, 669\left(\mathrm{M}^{-}\right) .{ }^{1} \mathrm{H}$ NMR $\left(\mathrm{CD}_{3} \mathrm{NO}_{2}\right) \delta 2.89(3 \mathrm{H}, \mathrm{q}, \mathrm{br}, J=6 \mathrm{~Hz}, \mathrm{NMe}), 4.76,4.80$ $\left(\right.$ each $\left.1 \mathrm{H}, \mathrm{AB}, J_{\text {gem }}=10 \mathrm{~Hz}, \mathrm{CH}_{2} \mathrm{NO}_{2}\right), 4.95(1 \mathrm{H}, \mathrm{q}$, $J(\mathrm{~F}-\mathrm{H})=1 \mathrm{~Hz}, J(\mathrm{Pt}-\mathrm{H})=13 \mathrm{~Hz}$, adduct $/ \mathrm{hfac}-\mathrm{CH}), 6.23$ $(1 \mathrm{H}, J(\mathrm{Pt}-\mathrm{H})=8 \mathrm{~Hz}, \mathrm{hfac}-\mathrm{CH}), 6.51,6.64,6.77($ each $1 \mathrm{H}$, $\left.\mathrm{MeNH}_{3}\right) .{ }^{13} \mathrm{C} \mathrm{NMR}\left(\left(\mathrm{CD}_{3}\right)_{2} \mathrm{CO}\right) \delta 34.1(\mathrm{NMe}), 80.9$ $\left(\mathrm{CH}_{2} \mathrm{NO}_{2}\right), 94.6$ (adduct/hfac-CH), $97.2(\mathrm{hfac}-\mathrm{CH}) .{ }^{19} \mathrm{~F}$ NMR $\left(\mathrm{CD}_{3} \mathrm{NO}_{2}\right) \delta 85.7$ (sl. br), $90.3(J(\mathrm{Pt}-\mathrm{F})=13 \mathrm{~Hz})$, $90.5(J(\mathrm{Pt}-\mathrm{F})=18 \mathrm{~Hz}), 90.5(J(\mathrm{Pt}-\mathrm{F})=18 \mathrm{~Hz}), 93.0$ $(J(\mathrm{Pt}-\mathrm{F})=17 \mathrm{~Hz})$. Anal. Calcd for $\mathrm{C}_{12} \mathrm{H}_{10} \mathrm{~N}_{2} \mathrm{O}_{6} \mathrm{~F}_{12} \mathrm{Pt}$ : C, $20.55 ; \mathrm{H}, 1.44 ; \mathrm{N}, 3.99 \%$. Found: C, 20.61; H, 1.44; N, $4.25 \%$.

8 The sample solution and the electrospraying needle were cooled at $-20{ }^{\circ} \mathrm{C}$ to increase the signal intensities of some short-lived species.

9 Crystallographic data for $4 ; \mathrm{C}_{19} \mathrm{H}_{24} \mathrm{NO}_{5} \mathrm{~F}_{12} \mathrm{Pt}$, FW = 753.46, monoclinic, $C 2 / c, a=19.958(10), b=15.733(4), c=$ 17.585(5) $\AA, \beta=101.51(3)^{\circ}, V=5410(3) \AA^{3}, Z=8$. Refinement of 344 parameters for 7848 reflections by full matrix gave final $R 1=0.0739$ (for $F_{\mathrm{O}}>4.0 \sigma\left(F_{\mathrm{o}}\right)$ ), $R w 2=$ 0.2539 (for all data) and $S=1.048$. The high $R 1$ value is due to the poor quality of the crystal.

10 S. Aygen, Y. Kitamura, K. Kuroda, R. Kume, H. Kelm, and R. van Eldik, Inorg. Chem., 24, 423(1985); S. Aygen, E. F. Paulus, Y. Kitamura, R. van Eldik, Inorg. Chem., 26, 769 (1987).

11 Crystallographic data for $\mathbf{6} ; \mathrm{C}_{12} \mathrm{H}_{10} \mathrm{~N}_{2} \mathrm{O}_{6} \mathrm{~F}_{12} \mathrm{Pt}$, FW = 701.28, triclinic, $P \overline{1}, a=10.889(4), b=11.111(2), c=$ 8.938(6) $\AA, \alpha=92.89(4), \beta=104.76(4), \gamma=110.54(2)^{\circ}, V$ $=967.5(8) \AA^{3}, Z=2$. Refinement of 314 parameters for 5635 reflections by full matrix gave final $R 1=0.0449$ (for $F_{\mathrm{O}}>4.0 \sigma\left(F_{\mathrm{O}}\right)$ ), $R w 2=0.1201$ (for all data) and $S=1.004$.

12 In $\mathrm{CD}_{3} \mathrm{OD}$ an $\mathrm{AB}$ quartet $\left(\delta 4.83,4.87 ; J_{\text {gem }}=12 \mathrm{~Hz}\right)$ assigned to $-\mathrm{CH}_{2} \mathrm{NO}_{2}$ diminished and a three line signal $(\delta$ 4.33, $J(\mathrm{H}-\mathrm{D})=2 \mathrm{~Hz})$ assigned to $\mathrm{CH}_{2} \mathrm{DNO}_{2}$ appeared. 